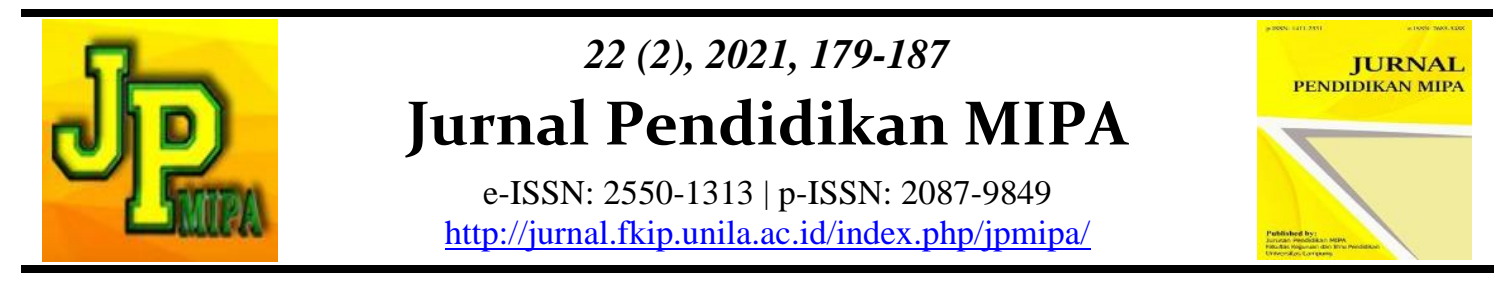

\title{
Evaluation of Online Learning Processes in FKIP Universitas Lampung During Covid-19 Pandemic
}

\author{
Afif Rahman Riyanda ${ }^{1, *}$, Ambiyar $^{2}$, Syahril $^{2}$, Fadhilah $^{2}$, Agariadne Dwinggo Samala $^{3}$, \\ Novi Hendri Adi ${ }^{4}$, Fattachul Huda Aminuddin ${ }^{5}$ \\ ${ }^{1}$ Department of Information Technology Education, Universitas Lampung, Indonesia \\ ${ }^{2}$ Department of Technology and Vocational Education, Universitas Negeri Padang, Indonesia \\ ${ }^{3}$ Department of Animation, Universitas Negeri Padang, Indonesia \\ ${ }^{4}$ Department of Technical Information, Universitas Ibnu Sina, Indonesia \\ ${ }^{5}$ Department of Information Systems, Universitas Nurdin Hamzah, Indonesia
}

\begin{abstract}
This article aims to explain the evaluation of the online learning process during the COVID-19 pandemic at the teaching and education faculty of the University of Lampung using the CIPP model. From this study, it can be concluded that the level of achievement of the implementation of the online learning process on the context component obtained an average score of $4.17(83.59 \%)$ with a good category; the input component obtained an average score of $3.973(80.04 \%)$ with good category; the process component obtained an average score of 3,798 (76.88\%) with sufficient category. This means that the implementation of online learning is still not able to overcome obstacles such as the uneven distribution of internet services that can be accessed by students in the application of online learning. as well as the speed of internet network access which is still slow and product components that get an average score of 4,107 (82.13\%) in the good category. From the results of the study, it can be concluded that the implementation of online learning during the COVID-19 pandemic is quite good.
\end{abstract}

Keywords: online learning, Covid-19 pandemic, CIPP Model.

\begin{abstract}
Abstrak: pandemi covid-19 telah menyebar keseluruh dunia termasuk indonesia, hal ini mengakibatkan terjadinya transformasi sistem pembelajaran secara online. Artikel ini bertujuan untuk menjelaskan evaluasi proses pembelajaran daring dimasa pandemi covid-19 di lingkungan fakultas keguruan dan ilmu pendidikan Universitas Lampung dengan mengadopsi CIPP model. Metode yang digunakan dalam penelitian ini adalah metode kuantitatif dengan Jenis data yaitu data primer. Dari penelitian dapat disimpulkan bahwa tingkat pencapaian pelaksanaan proses pembelajaran daring pada komponen context memperoleh skor rata-rata 4,17 (83,59\%) dengan kategori baik; komponen input memperoleh skor rata-rata 3,973 (80,04\%) dengan kategori baik; komponen process memperoleh skor rata-rata 3,798 (76,88\%) dengan kategori cukup. Artinya dalam pelaksanaan pembelajaran daring masih belum mampu mengatasi kendala seperti belum meratanya distribusi layanan internet yang dapat diakses oleh mahasiswa dalam penerapan pembelajaran daring. dan juga kecepatan akses jaringan internet yang masih lambat dan komponen product yang memperoleh skor rata-rata 4,107 (82,13\%) dengan kategori baik. Dari hasil penelitian dapat disimpulkan bahwa pelaksanaan pembelajaran daring si masa pandemi covid-19 dilingkungan PMIPA FKIP Unila secara keseluruhan sudah lumayan baik.
\end{abstract}

Kata kunci: pembelajaran daring, pandemi Covid-19, model CIPP.

\section{- INTRODUCTION}

Afif Rahman Riyanda et al.

Email: afif.rahman@fkip.unila.ac.id
DOI: http://dx.doi.org/10.23960/jpmipa/v22i2.pp179-187

Received: 16 October 2021

Accepted: 15 December 2021 
The World Health Organization (WHO) has declared the Corona Virus Disease 2019 (Covid-19) status as a pandemic, meaning that this outbreak has spread globally. Covid-19 has had a major impact on the survival of human life in all corners of the world, including Indonesia. Various efforts have been made to reduce the spread of this virus, one of which is by restricting movement in public spaces. The Indonesian government urges the public to always maintain physical distancing, worship, work and learn from home. (Zendrato, 2020).

Following up on the appeal, a number of educational institutions have adopted a policy of enforcing study rules at home. According to the Head of Media and Public Opinion of the Ministry of Busroni, social distancing and self-quarantine play a major role in prevention and handling to slow down the transmission of COVID-19, but there is no meaning if using the holiday period for holidays outside is the same as transferring contacts with other people. Social distancing must be adhered to and implemented by restraining oneself at home, not making contact with other people. In supporting the government's efforts to suppress the spread of COVID-19, Universitas Lampung, which is one of the State Universities in Indonesia, has also implemented an online learning system since April 2019. During the pandemic, the implementation of learning in Indonesia has undergone a transformation from face-to-face learning to face-to-face learning. advance into online learning (Suana et. al, 2019; Madya, 2021).

Online learning is a learning cycle that is done essentially that uses web innovation as a technique for associating in learning like the conveyance of material. (Mustofa et al., 2019). Online learning is a lot of required in learning in the period of the modern insurgency 4.0 (Pangodian, et, al, 2019). Online talks are one of the web based learning strategies or are helped out through the web organization (Sriyanto, 2019). Online learning will be discovering that can unite understudies and teachers to lead learning communications with the assistance of the web (Keller, et al, 2021). Online learning should be possible with computer offices, computer and cell phones associated with the web organization. School establishments and advanced education can use the Learning Management System as one of the applications in the execution of the internet learning process. What's more, there are a few applications that can be utilized in the internet learning interaction, for example, google homeroom or Office 365 applications, just as video conferencing applications that can be utilized during learning. (Cheng, Qu, Tian, Duan, \& Hakonarson, 2020). The internet learning framework can advance the communication among speakers and understudies through conversation gatherings contained in web-based media. The internet learning framework has been carried out at the Universitas Lampung as far as addressing the local area's requirement for advanced education benefits just as one type of understanding the Industrial Revolution 4.0 which centers around innovation based learning. Online learning at the Universitas Lampung as V-Class (Riyanda, 2020)

The use of V-Class is able to present learning virtually, the application of V-Class in the learning process is able to create a more effective learning process (Riyanda, 2020). Using web media allows students to obtain data information so that the explanation given to students is more interesting and complete. Teacher and students should always access and share information quickly. Rusman (2011), "Changes in the demands for integrating technology in learning activities make the world of education require innovation and creativity in the learning process, one of which is the use of web-based learning media in teaching and learning activities". 
However, in practice, the online learning process does not work as expected. Not a few students complain about online learning. In addition to increasing the cost burden for quota purposes, students also do not get relief in terms of paying tuition fees (Riyanda, 2020; Dewantara \& Nurgiansah, 2021). The application of the online learning system in the Covid-19 era still causes several problems (Ahmed, 2020). In accordance with that Gunadha and Rahmayunita (2020) the challenges looked during the web based learning process incorporate unsupportive signs, a few understudies need standard, numerous aggravations when learning at home, understudies feel less centered around learning without direct connection with instructors and different understudies, material introduced hard to comprehend, absence of preparation of teachers in setting up the material. The accessible areas of interest are lopsided and the web access speed is still sluggish (Riyanda, 2020; Adi, 2018). As to effect of web based learning on learning rehearses in schools, Zounek (2013) tracked down various instances of positive and adverse consequences. A portion of the positive effects are that educators and understudies are more acquainted with media or innovation learning stages like email, Google Meet, and Zoom Meetings. What's more, understudies are turning out to be increasingly more free since they need to take care of undertakings for the most part all alone. As to adverse consequences, sony (2020) reports various models, for example, instructors who are not knowledgeable about IT innovation might be extremely befuddled with regards to how to utilize web based learning stages, restricted web access can likewise add to fruitless execution of web based learning and result in adverse consequences. eventually. Similar obstacles were also experienced by Lampung University students, including there were students who experienced network problems during lectures, so that the learning process was not optimal. Another obstacle that the author faces is the limitations of the practicum tools owned by students, making the practicum process not run optimally.

Departing from field problems, the author feels the need to evaluate the online learning system process. Program evaluation is a systematic investigative activity about something valuable from an object (Muryadi, 2017). Program evaluation is not only done at the end of the program, but must be done from the beginning, namely from the preparation of the program design, program implementation and program results (Muryadi, 2017).

This study aims to reveal the online learning process during the Covid-19 pandemic in the information technology education study program at the Universitas Lampung seen from the Context, Input, Process components. In general, the purpose of this study is to explain the description of the implementation of online learning during the COVID-19 pandemic at the University of Lampung.

\section{- METHOD}

Based on the problems in this study, the type of research that will be done is program evaluation research. This research includes research that produces recommendations for improvement of a program. The evaluation model used is the CIPP model. Research is focused on explaining online learning system programs reviewed from Context, Input, Process, Product. This research is expected to explain the picture of the implementation of online learning systems in the FKIP Environment of Lampung University.

The approaches or methods used in this research are quantitative methods. With a descriptive approach. The sample was used by 250 students and 100 lecturers. The type 
of data used in the evaluation of online learning is primary data, meaning that data directly obtained from research subjects, namely students, and lecturers.

The research instruments used to collect the data in this study are as follows; (1) The data collection techniques used in this study with questionnaires (questionnaires). This study uses closed questionnaires, where communication is done in an indirect way. Informants / respondents are asked to choose an answer that suits their characteristics by giving a sign on the questionnaire sheet

\section{- RESULT AND DISCUSSION}

Assessment of the web based learning process is completed to work on the quality and work on the nature of picking up during the pandemic. The internet learning assessment plans to evaluate the execution of the learning system during the execution of the Universitas Lampung Chancellor's allure with respect to the execution of taking in completed from home so as not to make the grounds another bunch for the spread of the Codid-19 infection in the Universitas Lampung, especially in the teaching and education faculty of the University of Lampung. The model adopted in conducting this evaluation is using the CIPP model (context, input, process, and product).

A review of the implementation of the online learning process in terms of components based on the CIPP model. The things that are reviewed include the components of context, input, process, and product. The discussion of each component is explained as follows.

\section{Context Components}

The design component aims to develop the resources needed to carry out activities in achieving goals (Fitzpatrick, 2004). The context component in this evaluation research has three indicators and the following results are obtained. First, the indicator of online learning objectives obtained a TPR of $86,39 \%$ which is in the very good category. Second, the indicator of the need for the implementation of online learning obtained a TPR value of $81,63 \%$ with a good category. Third, indicators of the environment for the implementation of online learning obtained a TPR value of $82.75 \%$ in a good category. From the indicators above, it can be concluded that the implementation of online learning during the COVID-19 pandemic in the faculty of mathematics and natural science education environment is quite good, but there are still some notes that must be improved to get better results. Respondents' Achievement Results in context components are presented as follows:

Table 1. Respondents' achievement results on the context component

\begin{tabular}{|c|c|c|c|c|c|c|c|c|c|}
\hline \multirow{3}{*}{ No } & \multirow{3}{*}{ Indicator } & \multicolumn{5}{|c|}{ Statement Criteria } & \multirow{3}{*}{$\begin{array}{l}\text { Average } \\
\text { score }\end{array}$} & \multirow{3}{*}{ RAL } & \multirow{3}{*}{ Category } \\
\hline & & $(\%)$ & $(\%)$ & $(\%)$ & $(\%)$ & $(\%)$ & & & \\
\hline & & SS & $\mathrm{S}$ & RG & $\mathrm{TS}$ & STS & & & \\
\hline 1 & $\begin{array}{l}\text { The purpose of } \\
\text { implementing } \\
\text { online learning }\end{array}$ & 50,56 & 35,14 & 11,11 & 2,08 & 1,11 & 4,32 & 86,39 & Good \\
\hline 2 & $\begin{array}{l}\text { The need for } \\
\text { online learning }\end{array}$ & 58,96 & 15,63 & 8,54 & 8,33 & 8,54 & 4,08 & 81,63 & Good \\
\hline 3 & $\begin{array}{l}\text { Online learning } \\
\text { implementation } \\
\text { environment }\end{array}$ & 41,67 & 38,33 & 12,92 & 6,25 & 0,83 & 4,14 & 82,75 & Good \\
\hline
\end{tabular}




\section{Input components}

The input component in this evaluation research has four indicators and the following results are obtained. First, the indicator of educators with sub-indicators of educational background and competence of educators obtained a TPR of $88.27 \%$ in the very good category. This means that educators have good educational qualifications and competencies in implementing online learning during the pandemic. Second, the student indicators with sub-indicators of student background and student abilities obtained a TPR of $82.22 \%$ with a good category. The readiness and ability of students in the application of online learning is quite good, this is due to the ability of students to utilize technology, especially the ability to access excellent learning resources and the experience gained when carrying out lectures using hybrid learning that has been implemented by the University of Lampung before the period covid-19 pandemic. Third, facilities and infrastructure indicators with sub-indicators namely the availability of facilities (internet, laptops, and electricity networks) obtained a TPR of $63.55 \%$ in the sufficient category. This is due to the lack of adequate facilities and infrastructure owned by students, especially infrastructure in the field of internet services. The difference between students who live in urban areas and students who live in the regions greatly affects the quality of the network obtained. As a result, the online learning process is often disrupted. A similar obstacle was also conveyed by Fikri (2021) in his research that the basic obstacle experienced by students in the implementation of online learning was the problem of the internet network. Therefore, the government and companies engaged in internet providers need to improve and add facilities in order to create an even distribution of internet network quality so that it can be enjoyed by all people. Fourth, indicators of learning tools with sub-indicators of syllabus and RPS obtained TPR of $86.12 \%$ with good category. This shows that the quality of the learning tools provided by educators during the online learning process is good.

Based on the four indicators and each sub-indicator of the input component, it is stated that educators, students, facilities and infrastructure, and learning devices are in accordance with the opinion of Widoyoko (2010) which states that in the evaluation process, the input component consisting of human resources, facilities and infrastructure as well as the procedures and rules needed, it is necessary to carry out a comparison strategy of problem solving and the design of the relevant stages of activities in the implementation of online learning (Gentili, 2017).

Table 2. Respondents' achievement results on the input components

\begin{tabular}{|c|c|c|c|c|c|c|c|c|c|}
\hline \multirow{3}{*}{ No } & \multirow{3}{*}{ Indicator } & \multicolumn{5}{|c|}{ Statement Criteria } & \multirow{3}{*}{$\begin{array}{l}\text { Average } \\
\text { score }\end{array}$} & \multirow{3}{*}{ RAL } & \multirow{3}{*}{ Category } \\
\hline & & $(\%)$ & $(\%)$ & $(\%)$ & $(\%)$ & $(\%)$ & & & \\
\hline & & SS & $\mathrm{S}$ & $\mathrm{RG}$ & TS & STS & & & \\
\hline 1 & $\begin{array}{l}\text { Lecturer educational } \\
\text { background and } \\
\text { educator competence }\end{array}$ & 68 & 28,42 & 2,67 & 0,75 & 0,17 & 4,41 & 88,27 & Good \\
\hline 2 & $\begin{array}{l}\text { Student background } \\
\text { and student abilities }\end{array}$ & 36,5 & 41,11 & 19,78 & 2,22 & 0,39 & 4,11 & 82,22 & Good \\
\hline 3 & $\begin{array}{l}\text { Availability of } \\
\text { facilities }\end{array}$ & 50,83 & 21,46 & 12,71 & 5,42 & 9,58 & 3,06 & 63.55 & Poor \\
\hline 4 & $\begin{array}{l}\text { Syllabus and learning } \\
\text { tools }\end{array}$ & 48,33 & 38,57 & 9,76 & 2,02 & 1,31 & 4,30 & 86,12 & Good \\
\hline
\end{tabular}




\section{Process components}

The process component in this evaluation research has five indicators and the following research results are obtained. First, the indicators of the learning process with the sub-indicators of the online learning implementation process, obtained a TPR of $85.49 \%$ in the good category. This means that the learning process is carried out well. Second, indicators of educator activity obtained TPR of $87.75 \%$ with good category. That is, student activities while implementing the online learning system. also been going well. This can be seen from the positive responses from students regarding the activities of educators in learning activities. Third, the indicator of student activity with sub-indicators of the use of infrastructure in the implementation of the online learning system, based on the data obtained quantitatively, the TPR was $86,76 \%$ with a good category. This shows that student activities are going well in utilizing existing facilities, so that the learning process can continue to be carried out properly. Fourth, the constraint indicator with the sub-indicator of obstacles in the process of implementing the online learning system, obtained a TPR of $42 \%$ with a very poor category. This means that in the implementation of online learning, they are still unable to overcome obstacles such as the uneven distribution of internet services accessed by students for online learning. and also the speed of internet network access which is still slow for students. However, with all the limitations that exist, the learning process can still be carried out. In line with that, Aprianto (2020) in his writing said that the learning process is expected to continue to be carried out properly by utilizing existing facilities. Fifth, the solution indicator obtained a TPR of $81.63 \%$ in the good category. This proves that the solutions offered are responded positively by students, it is hoped that the government and companies engaged in internet providers need to improve and add facilities in order to create an even distribution of internet network quality so that it can be enjoyed by all people in accordance with needs and improve the quality of internet network access.

Based on five indicators / sub-indicators of the process component stated that the learning process, educator activity, student activity has been running well. But for the obstacles faced in the online learning system program is still not in line with expectations. However, the solutions that have been given should be taken seriously by the government and internet service providers. This is in line with the opinion of Worthen and Sandars (1973) who said that the process component can be used to predict an implementation plan during the implementation phase of the program, provide information in making decisions and be able to overcome obstacles that occur and as an archive in overcoming obstacles with the solutions offered.

Table 3. Respondents' achievement results on the process components

\begin{tabular}{|c|c|c|c|c|c|c|c|c|c|}
\hline \multirow{3}{*}{ No } & \multirow{3}{*}{ Indicator } & \multicolumn{5}{|c|}{ Statement Criteria } & \multirow{3}{*}{$\begin{array}{c}\text { Average } \\
\text { score }\end{array}$} & \multirow{3}{*}{ RAL } & \multirow{3}{*}{ Category } \\
\hline & & $(\%)$ & $(\%)$ & $(\%)$ & $(\%)$ & $(\%)$ & & & \\
\hline & & SS & $S$ & RG & $\mathrm{TS}$ & STS & & & \\
\hline 1 & $\begin{array}{l}\text { Online learning } \\
\text { implementation } \\
\text { process }\end{array}$ & 50,56 & 35,14 & 9,11 & 4,08 & 1,11 & 4,12 & 86,39 & Good \\
\hline 2 & Educator activities & 52,67 & 35,75 & 9,67 & 1,5 & 0,42 & 4,39 & 87,75 & Good \\
\hline 3 & $\begin{array}{l}\text { Utilization of } \\
\text { infrastructure } \\
\text { facilities in the }\end{array}$ & 57,74 & 26,55 & 10,24 & 2,74 & 2,74 & 4,34 & 86,67 & Good \\
\hline
\end{tabular}




\begin{tabular}{llllllllll}
\hline \multicolumn{2}{l}{$\begin{array}{l}\text { implementation of } \\
\text { online learning }\end{array}$} & & & & & & & & \\
\hline & $\begin{array}{l}\text { Obstacles in the } \\
\text { process of } \\
\text { implementing online } \\
\text { learning }\end{array}$ & 48,83 & 21,46 & 5,71 & 10,42 & 9,58 & 2,065 & 42 & $\begin{array}{l}\text { Very } \\
\text { Poor }\end{array}$ \\
\hline 5 & Solution & 58,96 & 15,63 & 8,54 & 8,33 & 8,54 & 4,081 & 81,63 & Good \\
\hline
\end{tabular}

\section{Product components}

The product component in this evaluation research has two indicators and the following research results are obtained. First, the result indicator obtained a TPR of $84.26 \%$ in the good category. This shows that the learning achievement of students who take part in the online learning system program is good. This means that students have been able to understand the purpose of implementing the online learning system. Second, the impact indicator with the sub-indicator of the impact of the implementation of the online learning system obtained TPR data of $80.00 \%$ with a good category. This means that students feel the positive impact of online learning programs.

Table 4. Respondents' achievement results on the product components

\begin{tabular}{|c|c|c|c|c|c|c|c|c|c|}
\hline \multirow{3}{*}{ No } & \multirow{3}{*}{ Indicator } & \multicolumn{5}{|c|}{ Statement Criteria } & \multirow{3}{*}{$\begin{array}{l}\text { Average } \\
\text { score }\end{array}$} & \multirow{3}{*}{ RAL } & \multirow{3}{*}{ Category } \\
\hline & & $(\%)$ & $(\%)$ & $(\%)$ & $(\%)$ & $(\%)$ & & & \\
\hline & & SS & $S$ & RG & TS & STS & & & \\
\hline 1 & $\begin{array}{l}\text { Results of achieving } \\
\text { learning objectives }\end{array}$ & 43,10 & 37,86 & 16,43 & 2,50 & 0,12 & 4,21 & 84,26 & Good \\
\hline 2 & $\begin{array}{l}\text { Impact of } \\
\text { implementation }\end{array}$ & 26,25 & 50,21 & 21,46 & 1,46 & 0,63 & 4,00 & 80,00 & Good \\
\hline
\end{tabular}

\section{- CONCLUSION}

Based on the results of research and discussion, from the four components evaluated, it can be concluded that context component: the purpose of the online learning program is good, meaning that the program has succeeded in achieving its goal of creating learning that can be carried out anywhere; the need for the implementation of online learning is quite good, meaning that most students need online learning in the learning process during the covid-19 pandemic; The environment for implementing the online learning system program is also quite good, meaning that the student living environment meets the requirements for the implementation of the online learning program. Input component: educators who apply online learning are very good in terms of educational background and abilities, but there are still educators who need to improve their competence in implementing online learning; students who take part in online learning programs are also classified as good, the facilities and infrastructure in the application of online learning are not good, this is because the quality of internet services is still not evenly distributed. There is a gap between students who are in the city and students who come from the regions. Students who are in the city will be free to access the internet network and can even choose a provider to connect, while students who come from regions will find it difficult to connect, there are even some areas that are not touched by internet services. Learning tools in the implementation of online learning. classified as good, but there are still shortcomings in terms of learning resources for students such as not all lecturers provide video tutorials for the learning process. 
Process component: the process of implementing online learning during this pandemic has gone well; student activities are classified as good, this is responded positively by students in the statement items given; so that student activities during the implementation of online learning run well. Furthermore, the obstacles faced during online learning are still not resolved quickly, meaning that the government and companies engaged in internet service providers are still lacking in overcoming the obstacles that occur, such as the unequal internet access available and also the speed of internet network access. still slow; The solutions offered in the online learning system program are well received, meaning that students expect the government and also companies engaged in internet service providers to be able to overcome existing problems, especially equitable access and improve the quality of internet network access so that the implementation of online learning during the pandemic can goes well.Product component: the achievement results from the implementation of online learning are classified as good, meaning that students have been able to understand the objectives of online learning; the impact of the implementation of the online learning system is also quite good, meaning that the impact obtained by students who have followed the online learning system has been good and positive, it can be seen from the learning outcomes of students who have carried out online learning.

\section{- REFERENCES}

Adi, N. H. (2018). Evaluasi program prakerin pada kompetensi keahlian teknik komputer dan jaringan di SMKN 2 Lubuk Basung. Jurnal Industri Kreatif, 2(1), 65-74.

Ahmed, S., Zimba, O., \& Gasparyan, A. Y. (2020). Moving towards online rheumatology education in the era of COVID-19. Clinical Rheumatology, 1-8.

Aprianto, A., Rizal, F., Lapisa, R., Wakhid, W., \& Riyanda, A. R. (2020). Curriculum Evaluation of Light Vehicle Engineering Department with Discrepancy Model as Per Industry Needs. Journal of Education Research and Evaluation, 4(4), 387-393.

Cheng, Z. J., Qu, H. Q., Tian, L., Duan, Z., \& Hakonarson, H. (2020). COVID-19: Look to the Future, Learn from the Past. Viruses, 12(11), 1226.

Dewantara, J. A., \& Nurgiansah, T. H. (2021). Efektivitas Pembelajaran Daring di Masa Pandemi COVID 19 Bagi Mahasiswa Universitas PGRI Yogyakarta. [Effectiveness of Online Learning during the COVID-19 Pandemic for PGRI Yogyakarta University Students]. Jurnal Basicedu, 5(1), 367-375.

Fikri, M., Faizah, N., Elian, S. A., Rahmani, R., Ananda, M. Z., \& Suryanda, A. (2021). Kendala Dalam Pembelajaran Jarak Jauh di Masa Pandemi Covid-19: Sebuah Kajian Kritis [Obstacles in Distance Learning during the Covid-19 Pandemic: A Critical Study]. Jurnal Education and Development, 9(1), 145-145.

Fitzpatrick, J. L. (2004). Exemplars as case studies: Reflections on the links between theory, practice, and context. American Journal of Evaluation, 25(4), 541-559.

Gentili, C. (2017). "Time out" for Classical Studies? The Future of Italian Liceo Classico in the 4.0 world.

Gunadha, R., \& Rahmayunita, H. (2020). Kuliah Online saat Corona Picu Ketimpangan Akses Bagi Mahasiswa Miskin. https://www.suara.com/news/2020/04/16/130712/ kuliah-online-saat-corona-picu-ketimpangan-akses-bagi- mahasiswa-miskin

Keller, J. M., Ucar, H., \& Kumtepe, A. T. (2021). Foundations of Motivational Research and Design in Online Distance Learning. In Motivation, Volition, and Engagement in Online Distance Learning (pp. 68-76). IGI Global. 
Madya, S. A. (2021, March). Online Learning Implementation in the Covid-19 Pandemic. In Ninth International Conference on Language and Arts (ICLA 2020) (pp. 26-31). Atlantis Press.

Muryadi, A. D. (2017). Model evaluasi program dalam penelitian evaluasi [Program evaluation model in evaluation research]. Jurnal Ilmiah Penjas (Penelitian, Pendidikan Dan Pengajaran), 3(1).

Mustofa, M. I., Chodzirin, M., Sayekti, L., \& Fauzan, R. (2019). Formulasi model perkuliahan daring sebagai upaya menekan disparitas kualitas perguruan tinggi [ The formulation of the online lecture model as an effort to reduce the disparity in the quality of higher education]. Walisongo Journal of Information Technology, 1(2), 151-160.

Pangondian, R. A., Santosa, P. I., \& Nugroho, E. (2019, February). Faktor-faktor yang mempengaruhi kesuksesan pembelajaran daring dalam revolusi industri 4.0. In Seminar Nasional Teknologi Komputer \& Sains (SAINTEKS) (Vol. 1, No. 1).

Riyanda, A. R. (2020). Kreativitas Belajar, Tingkat Pendidikan Orang Tua, Dan Pendapatan Orang Tua Terhadap Motivasi Belajar Siswa Smk Al-Huda Jatimulyo Kabupaten Lampung Selatan. Jurnal Inovasi Pendidikan dan Teknologi Informasi (JIPTI), 1(2), 56-61.

Riyanda, A. R., Herlina, K., \& Wicaksono, B. A. (2020). Evaluasi Implementasi Sistem Pembelajaran Daring Fakultas Keguruan dan Ilmu Pendidikan Universitas Lampung. IKRA-ITH HUMANIORA: Jurnal Sosial Dan Humaniora, 4(1), 66-71.

Soni, V. D. (2020). Global Impact of E-learning during COVID 19. Available at SSRN 3630073.

Sriyanto, W., \& Kaniadewi, N. (2019). Using Schoology in the era of IR 4.0 (Factors analysis from students' perception). International Journal for Educational and Vocational Studies, 1(5), 451-454.

Suana, W., Riyanda, A. R., \& Putri, N. M. A. A. (2019). Internet access and Internet selfefficacy of high school students. Journal of Educational Science and Technology, 5(2), 110-117.

Widoyoko, E. P. (2009). Evaluasi program pembelajaran [Evaluation of learning programs]. Yogyakarta: pustaka pelajar, 238.

Worthen, Blaine R., and James R. Sanders. Evaluation as disciplined inquiry. Educational evaluation: Theory and practice (1973): 10-39.

Zounek, J., \& Sudicky, P. (2013). Heads in the cloud: Pros and Cons of online learning. In International Conference DisCo New technologies and media literacy education, At Prague (pp. 59-62). 